\title{
Corrosion Study of Iron-Cobalt Alloys for MRI-Based Propulsion Embedded in Untethered Microdevices Operating in the Vascular Network
}

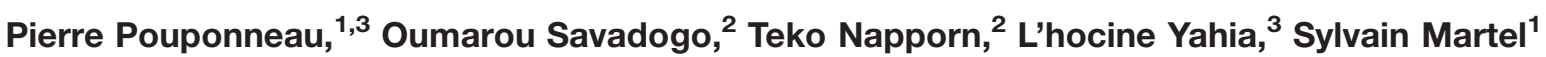 \\ ${ }^{1}$ Nanorobotics Laboratory, École Polytechnique de Montréal (EPM), Montréal, Canada \\ ${ }^{2}$ Laboratoire de Nouveaux Matériaux pour l'Électrochimie et l'Énergie, École Polytechnique de Montréal (EPM), Montréal, \\ Canada \\ ${ }^{3}$ Laboratory for the Innovation and Analysis of Bioperformance, École Polytechnique de Montréal (EPM), Montréal, Canada
}

Received 7 May 2009; revised 15 October 2009; accepted 17 October 2009

Published online 29 January 2010 in Wiley InterScience (www.interscience.wiley.com). DOI: 10.1002/jbm.b.31575

\begin{abstract}
Our group have shown in an experiment performed in the carotid artery of a living swine that magnetic gradients generated by a clinical magnetic resonance imaging (MRI) system could propel and navigate untethered medical microdevices and micronanorobots in the human vasculature. The main problem with these devices is that the metal necessary for magnetic propulsion may corrode and induce cytotoxic effects. The challenge, then, is to find an alloy with low corrosion yet providing an adequate magnetization level for propulsion in often stringent physiological conditions. Because of their high magnetization, we studied the corrosion behavior of two iron-cobalt alloys, Permendur $(49 \% \mathrm{Fe}, 49 \% \mathrm{Co}, 2 \% \mathrm{~V})$ and Vacoflux $17(81 \% \mathrm{Fe}, 17 \% \mathrm{Co}, 2 \% \mathrm{Cr})$, in physiological solution by potentiodynamic polarization assay, surface analysis, and corrosion electrolyte analysis. Both alloys exhibited low corrosion parameters such as a corrosion potential $\left(\boldsymbol{E}_{\text {corr }}\right)$ of $-0.57 \mathrm{~V} / \mathrm{SCE}$ and $\boldsymbol{E}_{\text {corr }}$ of $\mathbf{- 0 . 4 2} \mathrm{V} / \mathrm{SCE}$ for Vacoflux 17. The surface of Permendur samples was homogenously degraded. Vacoflux 17 surface was impaired by cracks and crevices. Both alloys had a stoichiometric dissolution in the electrolyte, and they released enough cobalt to induce cytotoxic effects. This study concluded that Fe-Co alloys could be used preferably in medical microdevices if they were coated so as not to come in contact with physiological solutions. (C) 2010 Wiley Periodicals, Inc. J Biomed Mater Res Part B: Appl Biomater 93B: 203-211, 2010
\end{abstract}

Keywords: corrosion; metal ions; degradation; iron-cobalt alloys; medical microdevices

\section{INTRODUCTION}

The development of untethered microdevices that can be steered in the blood vessels could benefit several minimally invasive surgeries or interventions. ${ }^{1}$ These new therapeutic microdevices, if small enough, could enhance target interventions in the microvasculature, such as in targeting tumors for therapeutic purposes. However, as the overall size of the microdevices is reduced, it becomes technologically more challenging to propel them. Different propulsion mechanisms have been proposed. ${ }^{2-4}$ However, the propulsion system and its embedded power source (usually a battery) require the device to be more than several millimeters in size. One solution that has been validated in vivo is the use of the magnetic field and magnetic gradients generated

Correspondence to: S. Martel (e-mail: sylvain.martel@polymtl.ca)

(C) 2010 Wiley Periodicals, Inc. by a clinical magnetic resonance imaging (MRI) system as the energy source for propulsion. ${ }^{5,6}$ It has been demonstrated that an MRI system allows the propulsion, tracking and control of the movement of the microdevice in the blood vessels. ${ }^{7,8}$ The in vivo assay confirmed the possibility of achieving controlled displacement of such microdevices by automatically steering a ferromagnetic bead along a preplaned path in the carotid artery of a living swine. ${ }^{5}$ The bead used for the in vivo assay was made of chrome steel with $1.7 \mathrm{~T}$ saturation magnetization $\left(M_{\mathrm{s}}\right)$ and a diameter of $1.5 \mathrm{~mm}$. The development of this magnetic microdevice entails investigating the biocompatibility of magnetic materials. Current metallic biomaterials such as titanium alloys, chromium-cobalt alloys, and 316L stainless steel alloys are not ferromagnetic materials. Accordingly, in the next section of this article, we selected several magnetic materials based on their magnetic properties for the propulsion and their corrosion resistance to determine the most suitable alloy for the microdevice. Then, we studied the corrosion 
behavior of two iron-cobalt alloys, because, during in vivo steering assays, corrosion can degrade the microdevice and releases toxic ions. Corrosion analysis was done by potentiodynamic polarization assays, surface characterizations by scanning electron microscopy (SEM), atomic force microscopy (AFM), and static contact angle (SCA) measurement and corrosion solution analysis by inductively coupled plasma time of flight mass spectrometry (ICP-TOF-MS) to identify and quantify the ion release.

\section{Selection of Iron-Cobalt Alloys for MRI-Based Propulsion}

Several magnetic materials have been considered for the propulsion system, taking into account their saturation magnetization and their corrosion resistance. The propulsion force being induced depends on three factors: the magnetic gradient applied, the volume of the ferromagnetic body, and the magnetization of the ferromagnetic material used. ${ }^{6}$ The magnetophoretic velocity $\left(V_{\mathrm{mag}}\right)$ of the microdevice assimilated as a bead made of ferromagnetic material in the blood flow at low Reynolds number is defined by:

$$
V_{\text {mag }}=\frac{M s \times V_{\text {microdevice }} \times \nabla B}{6 \Pi \times R_{\text {microdevice }} \times \mu}
$$

${ }^{9}$ with $M_{\mathrm{s}}=$ saturation magnetization of the magnetic material $(\mathrm{T}$ or $\mathrm{A} / \mathrm{m}), V_{\text {microdevice }}=$ microdevice volume $\left(\mathrm{m}^{3}\right)$, $R_{\text {microdevice }}=$ microdevice radius $(\mathrm{m}), \nabla B=$ magnetic gradient applied $(\mathrm{T} / \mathrm{m}), \mu=$ blood viscosity (Pa s). A clinical MRI system can generate a magnetic gradient of $0.04 \mathrm{~T} / \mathrm{m}$, and the blood viscosity is $0.0035 \mathrm{~Pa} \mathrm{~s}$.

Iron-cobalt alloys are known for their very high saturation magnetization of $2.35 \mathrm{~T} .^{10}$ The biocompatibility of this soft ferromagnetic alloy does not appear to have been studied extensively. Nd-Fe-B alloys are hard ferromagnetic materials with $M_{s}=1.6 \mathrm{~T}^{11}$ and they exhibit low corrosion resistance in physiological media. ${ }^{12,13}$ Corrosion resistance remains a major limitation for medical applications if surface treatments are not considered. The saturation magnetization of iron-nickel alloys $(\mathrm{Fe}-47.5 \% \mathrm{Ni})$ reaches 1.5 $\mathrm{T},{ }^{14}$ and its corrosion resistance appears limited. ${ }^{15-17}$ Stainless steel 304L (SS 304L) $(0.023 \%$ C; $18.22 \%$ Cr; $0.34 \%$ $\mathrm{Si} ; 8.58 \% \mathrm{Ni} ; 1.79 \% \mathrm{Mn} ; 0.43 \% \mathrm{Mo}$ ) usually presents a paramagnetic behavior. Therefore, this stainless steel can become ferromagnetic with $\alpha$ martensite structure. ${ }^{18}$ This alloy possesses good corrosion properties such as a large passivation interval in $\mathrm{NaCl}$ solution due to the formation of Cr-rich passive film, ${ }^{19,20}$ but its saturation magnetization remains $1.28 \mathrm{~T}^{18}$ To choose the most suitable ferromagnetic alloy for the propulsion, the theoretical magnetophoretic velocity of the microdevice depending on its diameter has been calculated in eq. (1), and the results are displayed in Figure 1. Because of its high saturation magnetization $\left(M_{\mathrm{s}}=2.35 \mathrm{~T}\right)$, Permendur (Fe-Co alloy) will allow a gain in the magnetophoretic velocity of $43 \%$ over chrome steel and $87 \%$ over SS 304L (Fig. 1). Moreover, Fe-Co alloys

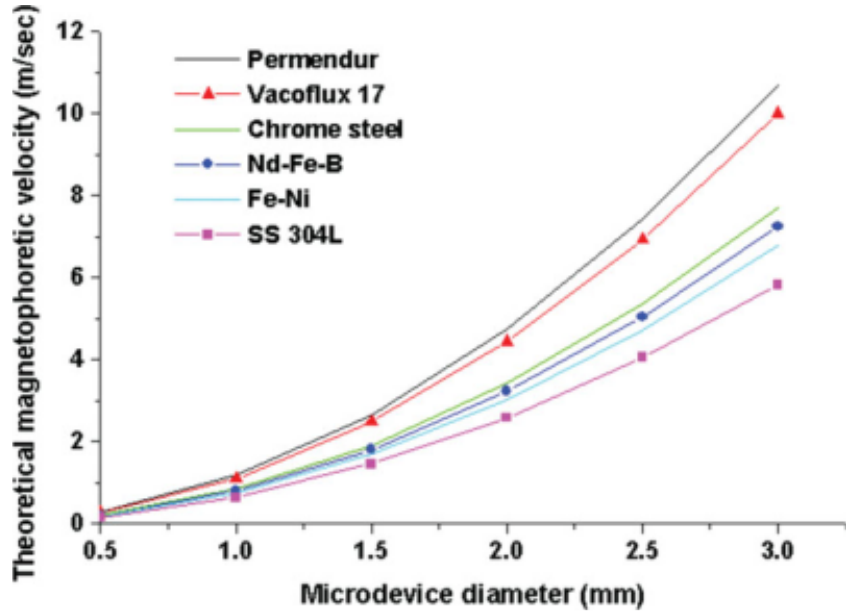

Figure 1. Theoretical magnetophoretic velocity of the microdevice as a function of the microdevice diameter for different magnetic materials with $0.04 \mathrm{~T} / \mathrm{m}$ magnetic gradient generated by $1.5 \mathrm{~T} \mathrm{MRI}$ system. Permendur $\left(M_{\mathrm{s}}=2.35 \mathrm{~T}\right)$ and Vacoflux $17\left(M_{\mathrm{s}}=2.2 \mathrm{~T}\right)$ are Fe-Co alloys. Chrome steel $\left(M_{\mathrm{s}}=1.7 \mathrm{~T}\right), \mathrm{Nd}-\mathrm{Fe}-\mathrm{B}$ alloy $\left(M_{\mathrm{s}}=\right.$ 1.6 T), Fe-47.5\% Ni $\left(M_{\mathrm{S}}=1.5 \mathrm{~T}\right)$, SS 304L $\left(M_{\mathrm{S}}=1.28 \mathrm{~T}\right)$. [Color figure can be viewed in the online issue, which is available at www.interscience.wiley.com.]

would allow further size reduction of the microdevice. For example, for both Permendur with a diameter of $1.3 \mathrm{~mm}$ and for SS 304L with a diameter of $1.75 \mathrm{~mm}$, the magnetophoretic velocity reaches $2 \mathrm{~m} / \mathrm{sec}$ (Fig. 1). Accordingly, it is required for the development of our microdevice to investigate the corrosion behavior of Fe-Co alloys.

\section{MATERIALS AND METHODS}

\section{Materials and Sample Preparation}

Two Fe-Co alloys were used: Permendur, supplied by the company Carpenter (England) and Vacoflux 17, supplied by the company Vacuumschmelze (Germany). Permendur is composed of $49 \% \mathrm{Fe}, 49 \% \mathrm{Co}, 2 \% \mathrm{~V}$, and its $M_{\mathrm{s}}$ reaches $2.35 \mathrm{~T}^{10}$ Vacoflux 17 is composed of $81 \% \mathrm{Fe}, 17 \% \mathrm{Co}$, $2 \% \mathrm{Cr}$, with an $M_{\mathrm{s}}$ of $2.2 \mathrm{~T}^{21}$ Unlike Permendur, Vacoflux 17 can be cold worked, which makes its processing easier. Both samples were $50 \mathrm{~mm}$ thick. The diameter of Permendur samples was $12 \mathrm{~mm}$, and that of Vacoflux 17 was $7 \mathrm{~mm}$. Three samples of each Fe-Co alloy were mechanically polished with $\mathrm{SiC}$ wet paper (240 and 400 grits). A mirror finish was obtained with alumina paste $(15,1$, and $0.05 \mu \mathrm{m})$. One surface of the sample was connected to a copper wire by conductive tape. The wire and the sample were embedded in epoxy resin. The exposed surface of the sample was polished. The copper wire was used to connect the sample to the corrosion setup. The electrical contact was checked throughout all the steps of the corrosion setup and sample preparation. Before the corrosion assay, the sample surface was cleaned with acetone then with methanol. 


\section{Potentiodynamic Polarization Assay}

This assay was done according to standard G5-94 of the American Society for Testing and Materials (ASTM). ${ }^{22}$ Cyclic polarization measurements were done using a standard three-electrode cell, a platinum grid as the counterelectrode, and a saturated calomel electrode (SCE) as the reference, with a micro-processor-controlled electronic potentiostat (model EG\&G, Princeton Applied Research, model 273). The electrolyte was $500 \mathrm{~mL}$ of Hank's physiological solution (Sigma Aldrich) with the following composition: $\mathrm{NaCl}: 8 \mathrm{~g} / \mathrm{L}, \mathrm{KCl}: 0.4 \mathrm{~g} / \mathrm{L}, \mathrm{NaHCO}_{3}: 0.35 \mathrm{~g} / \mathrm{L}$, $\mathrm{KH}_{2} \mathrm{PO}_{4}: 0.006 \mathrm{~g} / \mathrm{L}, \mathrm{Na}_{2} \mathrm{HPO}_{4}: 0.0475 \mathrm{~g} / \mathrm{L}$, glucose: $1 \mathrm{~g} / \mathrm{L}$, HEPES: $3.75 \mathrm{~g} / \mathrm{L}$. Before monitoring the potential, for 60 min, the solution was de-aerated with a strong flow of nitrogen gas. During the assay, the solution was maintained at $37^{\circ} \mathrm{C}$ under slow agitation and de-aerated by nitrogen gas bubbling. The sample was immersed in the Hank's solution and for $60 \mathrm{~min}$, the open circuit potential $\left(E_{\mathrm{ocp}}\right)$ was monitored. The potential scan started at $-250 \mathrm{mV}$ under $E_{\text {ocp }}$ value, and the anodic potential value was increased at a constant rate of $0.17 \mathrm{mV} / \mathrm{s}$ up to $0.8 \mathrm{~V} / \mathrm{SCE}$. Next, the anodic potential value was decreased to $-0.8 \mathrm{~V} / \mathrm{SCE}$ at the same rate. The corrosion current density $\left(i_{\text {corr }}, \mathrm{A} / \mathrm{cm}^{2}\right)$ was determined by Tafel extrapolation (CorrWare Version 2.9, Solartron Analytical). The corrosion rate $(C R, \mu \mathrm{m} / \mathrm{yr})$ was calculated based on the equivalent weight $(\mathrm{g})$, sample area $\left(\mathrm{cm}^{2}\right)$, and density $(\mathrm{g} / \mathrm{mL})$ values of the characterized samples. All potentials were expressed with reference to SCE. All the values were the average of three measurements.

\section{Surface Analysis}

The sample surface was characterized before and after the potentiodynamic polarization assays by several systems. AFM was done with a PicoSPM (Molecular Imaging) to determine the sample topography. The tips were made of silicone. The surface analysis area was $30 \times 30 \mu \mathrm{m}$, and the surface was analyzed three times. The average roughness was determined using the software embedded within the AFM system. SEM was done with a Hitashi S-3500N SEM, and the energy applied for the observations was $20 \mathrm{keV}$. Energy dispersive spectroscopy (EDS) was done with Inca Energy Oxford system. The static contact angle was determined with a video contact angle system VCA OPTIMA $^{\mathrm{TM}}$, Ast Products, Inc.). A $2 \mu \mathrm{L}$ droplet of deionised water was used, and the measure was taken after 5 seconds. The room temperature was $20^{\circ} \mathrm{C}$, and the relative humidity rate was $44 \%$. Height measurements were performed on each polished sample. Before each assay, samples were cleaned with acetone and methanol in an ultrasonic bath.

\section{Inductively Coupled Plasma Time of Flight Mass Spectrometry}

The supernatant and the precipitates taken from the corrosion electrolyte were used for these analyses. $\mathrm{HNO}_{3}$
TABLE I. ICP-TOF-MS Parameters

\begin{tabular}{|c|c|c|}
\hline ICP source & Hot plasma & Cool plasma \\
\hline Forward Power $(\mathrm{kW})$ & 1.4 & 0.75 \\
\hline Plasma flow $\left(\mathrm{L} \mathrm{mn}^{-1}\right)$ & 14.2 & 15.8 \\
\hline Auxiliary flow $\left(\mathrm{L} \mathrm{mn}^{-1}\right)$ & 0.8 & 1.1 \\
\hline Nebulizer flow $\left(\mathrm{L} \mathrm{mn}^{-1}\right)$ & 0.9 & 1.1 \\
\hline Detector (V) & -2300 & -2200 \\
\hline
\end{tabular}

Environmental grade (metals ions less than $100 \mathrm{ppb}$ ) was provided by Anachemia, and $5 \% \mathrm{HNO}_{3}$ matrix was prepared with deionized ultra pure water $(18.2 \mathrm{M} \Omega \mathrm{cm})$. To insure the dissolution of any solid particles, $1.0 \mathrm{~mL}$ of concentrated nitric acid was added to $0.5 \mathrm{~mL}$ of each supernatant. These solutions were diluted with a $5 \%$ nitric acid solution for the analysis. Also, $0.1829 \mathrm{~g}$ of Permendur precipitate and $0.1996 \mathrm{~g}$ of Vacoflux 17 precipitate were dissolved respectively in $1.0 \mathrm{~mL}$ of concentrated nitric acid. The solutions obtained were diluted with $5 \% \mathrm{HNO}_{3}$ for the analysis. $\mathrm{Co}, \mathrm{Cr}$, and $\mathrm{V}$ were analyzed under hot plasma while, for the Fe, cool plasma was preferred to minimize the interference of the $\mathrm{ArO}^{+}$at $\mathrm{m} / \mathrm{z} 56$. The analysis was performed with an ICP-TOF-MS model Renaissance axial from LECO. $^{23}$ The conditions of cool and hot plasma experiments are summarized in Table I. To avoid detector overload under hot plasma conditions, ions deflection for $\mathrm{N}^{+}, \mathrm{O}^{+}, \mathrm{H}_{2} \mathrm{O}^{+}, \mathrm{H}_{3} \mathrm{O}^{+}, \mathrm{N}_{2}{ }^{+}, \mathrm{O}^{+}, \mathrm{O}_{2} \mathrm{H}^{+}, \mathrm{Ar}^{+}, \mathrm{ArO}^{+}$, $\mathrm{Ar}_{2}{ }^{+}$were made. The liquid standards of $\mathrm{Co}, \mathrm{V}, \mathrm{Fe}, \mathrm{Cr}$, were provided by Inorganicventures $(\mathrm{C}$ and were used for the calibration. Before the calibration and the analyses, indium ion (contained in a so-called MassCal 10 standards) at $m / z 115$ signal was used in any condition (hot or cool plasma) to optimize the system. Each analysis was repeated four times to insure their reproducibility. The concentration of metallic elements was divided by the weight of the precipitate to compare the ion release of the two Fe-Co alloys.

\section{RESULTS}

\section{Potentiodynamic Polarization Assay}

Figure 2 and the data extracted from it (Table II) show that Permendur exhibited a corrosion potential $\left(E_{\text {corr }}\right)$ at $-0.57 \pm 0.01 \mathrm{~V} / \mathrm{SCE}$, and the corrosion current density reached $0.53 \pm 0.17 \mu \mathrm{A} / \mathrm{cm}^{2}$. Permendur exhibited a passivation interval between $-0.5 \mathrm{~V} / \mathrm{SCE}$ and $-0.4 \mathrm{~V} / \mathrm{SCE}$. On the other hand, on the reverse scan, the curve did not display hysteresis. Vacoflux 17 exhibited $E_{\text {corr }}$ of $-0.42 \pm$ $0.02 \mathrm{~V} / \mathrm{SCE}$ and $i_{\text {corr }}$ of $0.06 \pm 0.02 \mu \mathrm{A} / \mathrm{cm}^{2}$ (Fig. 3, Table II). During the forward scan, no active-passive transition was detected. On the reverse scan, the curve displayed a small hysteresis indicating pit or crevice formation on the sample surface. Permendur $E_{\text {ocp }}$ decreased from $-0.325 \mathrm{~V} / \mathrm{SCE}$ to $-0.380 \mathrm{~V} / \mathrm{SCE}$ and from $-0.31 \mathrm{~V} / \mathrm{SCE}$ to $-0.4 \mathrm{~V} / \mathrm{SCE}$ for Vacoflux 17 (Fig. 4). At the beginning 


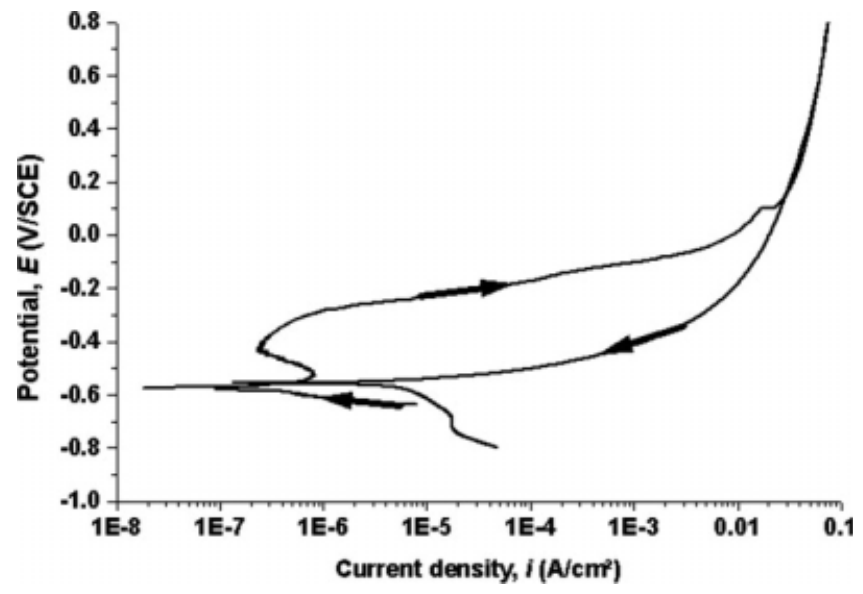

Figure 2. Permendur polarization curve. Arrows indicate the increase and the decrease of the applied potential during the potentiodynamic polarization assay.

of the assay, $E_{\text {ocp }}$ of Vacoflux 17 dropped from -0.31 $\mathrm{V} / \mathrm{SCE}$ to $-0.36 \mathrm{~V} / \mathrm{SCE}$ in $160 \mathrm{sec}$ (Fig. 4). Then, $E_{\text {ocp }}$ increased to $-0.35 \mathrm{~V} / \mathrm{SCE}$ and remained stable at this value during $700 \mathrm{sec}$ before decreasing. Table II summarizes the corrosion parameters measured during the polarization assay. The corrosion potential of Vacoflux 17 was higher than the one of Permendur. The corrosion rate of the Vacoflux 17 was not evaluated because this alloy exhibited pitting corrosion behavior.

\section{Surface Analysis}

Before the corrosion assay, the surface of each sample possessed a mirror finish without any polishing marks (SEM images not shown). AFM images of both Fe-Co sample surfaces before the corrosion assay have confirmed the quality of the polishing and the uniformity of the surface [Figs. 6(a) and 8(a)]. After the corrosion assay, SEM (Fig. 5) and AFM (Fig. 6) images show that the morphology of the Permendur surface has changed, and the surface has lost its mirror finish. However, the whole surface of Permendur samples was homogenously degraded, and no pits were detected (Fig. 5) as supported by the polarization curve analysis (Fig. 2). According to chemical analysis by EDS (Table III), the white deposit found on the sample surface (Fig. 5) is mainly composed of sodium and chloride, two main elements of the Hank's solution. According to SEM images of Permendur surface (image not shown), the amount of these insoluble salts deposited on the surface

TABLE II. Permendur and Vacoflux 17 Corrosion Parameters from the Potentiodynamic Polarization Assay. CR of Vacoflux 17 is Not Evaluated Because this Alloy Exhibits Pitting Corrosion Behavior

\begin{tabular}{lccc}
\hline Fe-Co alloys & $E_{\text {corr }}(\mathrm{V} / \mathrm{SCE})$ & $i_{\text {corr }}\left(\mu \mathrm{A} / \mathrm{cm}^{2}\right)$ & $C R(\mu \mathrm{m} / \mathrm{yr})$ \\
\hline Permendur & $-0.57 \pm 0.01$ & $0.53 \pm 0.17$ & $13 \pm 4$ \\
Vacoflux 17 & $-0.42 \pm 0.02$ & $0.06 \pm 0.02$ & - \\
\hline
\end{tabular}

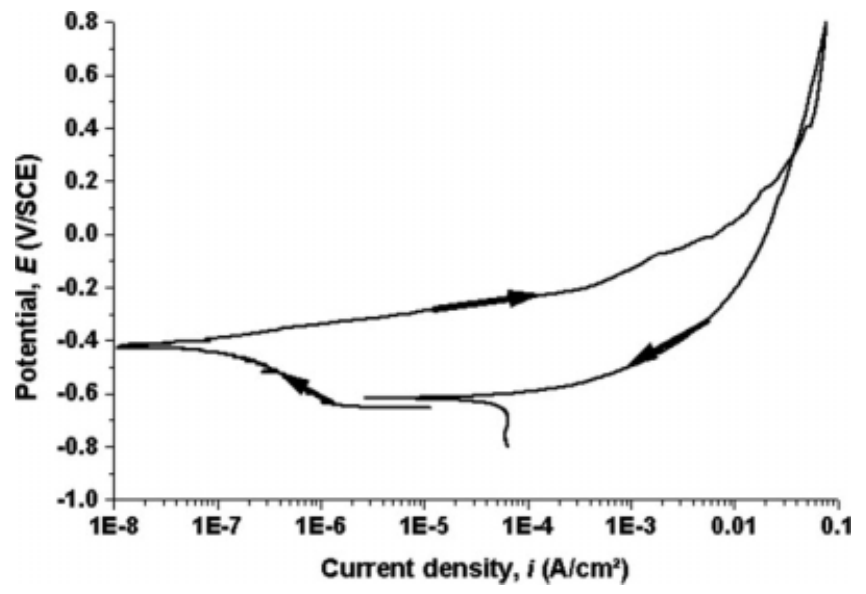

Figure 3. Vacoflux 17 polarization curve. Arrows indicate the increase and the decrease of the applied potential during the potentiodynamic polarization assay.

increased with the duration of the potentiodynamic polarization assay. Furthermore, the insoluble salts were deposited preferentially at the grain boundaries [Fig. 5(b)]. At high magnification, the Permendur polycrystal structure [Fig. 5(b)] was imaged because an electrolytic etching of the grain boundaries has occurred during the corrosion assay. ${ }^{24}$ After the corrosion assay, Permendur surface morphology has resulted from a uniform progressive surface degradation [Fig. 6(b)]. AFM image has confirmed that no pits were formed on Permendur sample surface [Fig. 6(b)].

Vacoflux 17 sample surface has changed after the corrosion assay (Figs. 7 and 8). As a matter of fact, the surface lost its mirror finishing, and it was different from the Permendur surface because it was cracked (Fig. 7). The length of the cracks varied from 7 to $20 \mu \mathrm{m}$, and the width remained between 1 and $2 \mu \mathrm{m}$ [Fig. 7(b)]. However, Vacoflux 17 samples displayed less insoluble salts on their surface than the Permendur samples (Figs. 5 and 7). AFM image [Fig. 8(b)] confirmed the damage to the surface and the presence of cracks. Unlike Permendur, Vacoflux 17

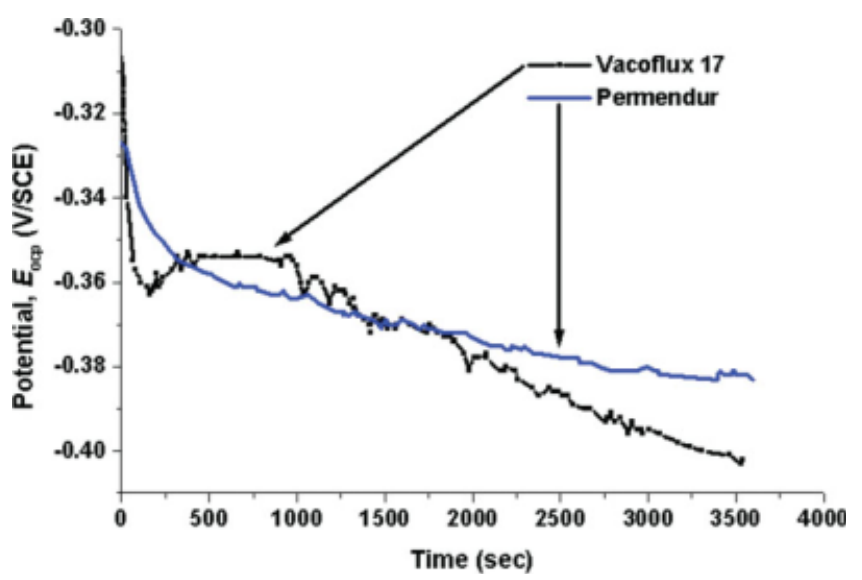

Figure 4. Open circuit potential $\left(E_{\mathrm{ocp}}\right)$ versus time for Permendur and Vacoflux 17. [Color figure can be viewed in the online issue, which is available at www.interscience.wiley.com.] 


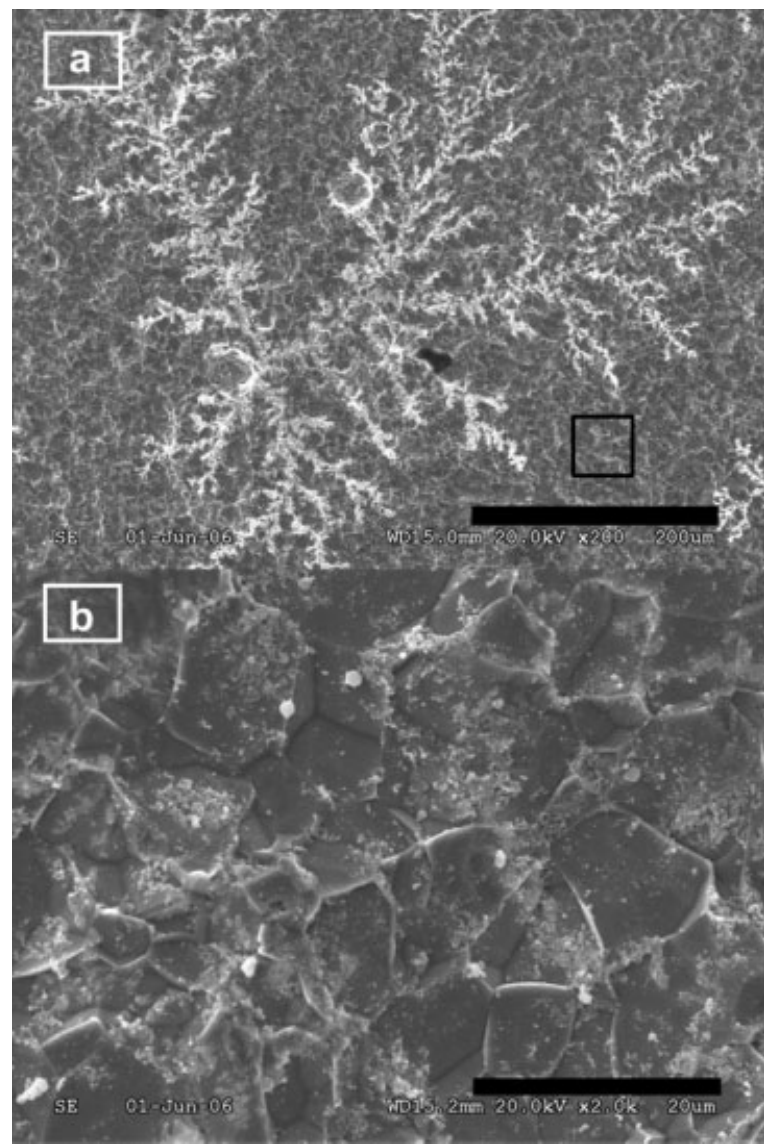

Figure 5. Permendur SEM observations after the corrosion assay (a: X200, scale bar $=200 \mu \mathrm{m}$; b: X2000- Region of interest indicated on image (a), scale bar $=20 \mu \mathrm{m})$.

surface degradation [Fig. 8(b)] was not the result of a uniform surface degradation process.

Before the corrosion assay, Vacoflux 17 roughness $(311 \mathrm{~nm})$ was higher than Permendur roughness $(261 \mathrm{~nm})$ (Table IV). After the corrosion assay, the roughness increased by $1500 \mathrm{~nm}$ for the Permendur samples and by $400 \mathrm{~nm}$ for Vacoflux 17 (Table IV). Vacoflux 17 static contact angle value remained higher than Permendur SCA value (Table V). As a result, Permendur surface appeared more hydrophobic than Vacoflux 17 surface. The standard deviation of the contact angle values remained higher for Vacoflux 17 than for Permendur. This difference can be correlated to the roughness measured for both Fe-Co alloys before the corrosion assay (Table IV).

\section{ICP-TOF-MS Analysis}

At the end of the corrosion assay, it was not possible to measure the sample weight loss because the sample was embedded in the epoxy resin. The chemical analysis of the electrolyte after the corrosion assay, using ICP-TOF-MS method, constitutes a good method to evaluate the relative degradation of the two Fe-Co alloys. According to the ICPTOF-MS analysis of Hank's solution after corrosion assays,

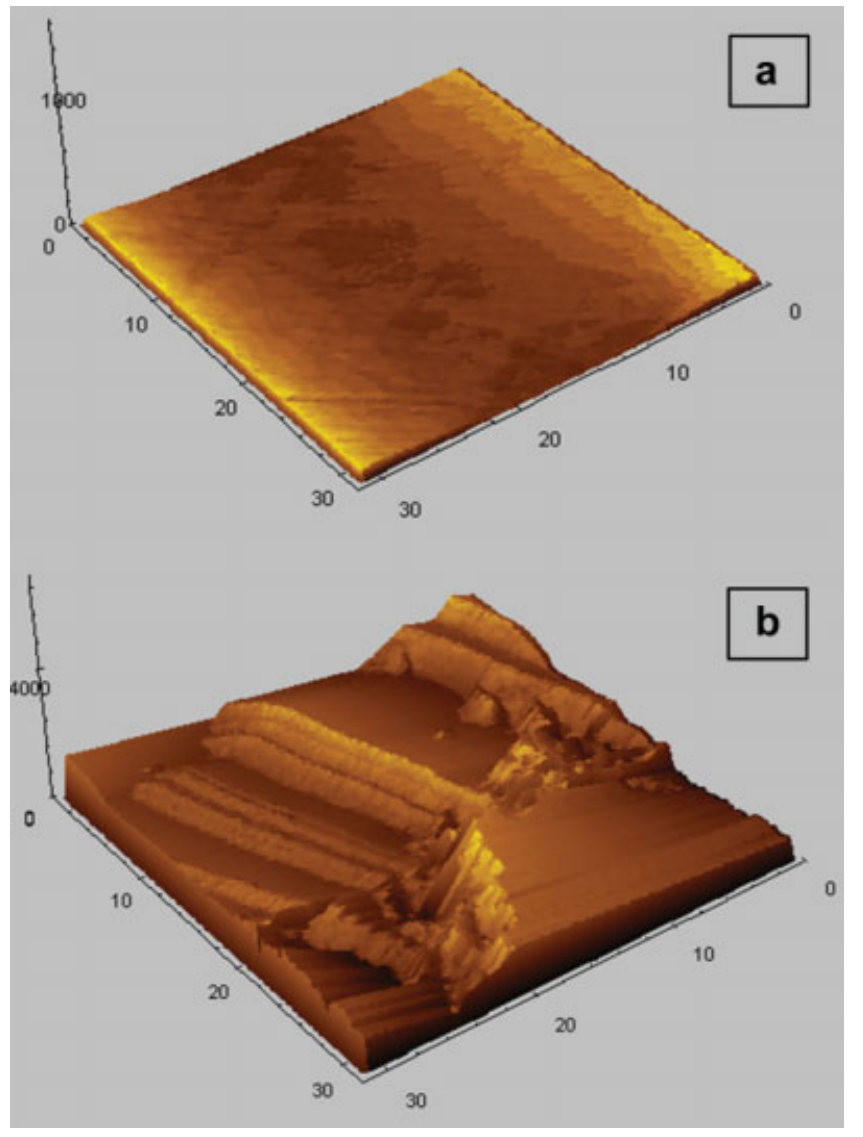

Figure 6. Permendur sample surface morphology (a: polished surface, b: surface after the corrosion assay). The scale is in $\mathrm{nm}$. [Color figure can be viewed in the online issue, which is available at www.interscience.wiley.com.]

the composition of the Permendur precipitates found in the electrolyte was $48.5 \% \mathrm{Fe}, 48.9 \% \mathrm{Co}, 2.6 \% \mathrm{~V}$, and the composition of the Vacoflux 17 precipitates was $80.2 \% \mathrm{Fe}$, $16.4 \% \mathrm{Co}, 2.8 \% \mathrm{Cr}$ (Table VI). The precipitates exhibited the same composition as the bulk alloy. Furthermore, the total amount of ions released was 18,291 ppb for Permendur and 16,917 ppb for Vacoflux 17. Permendur electrolyte contained higher amount of cobalt with $8971 \mathrm{ppb}$ than Vacoflux 17 electrolyte with $2771 \mathrm{ppb}$. The concentration of cobalt ions in the electrolyte supernatant reached $91 \mathrm{ppb}$ for Permendur and $7 \mathrm{ppb}$ for Vacoflux 17. Moreover, the concentration of cobalt ions in the supernatant of the Permendur electrolyte remained much higher than the concentration of iron ions. Finally, the chromium ion

TABLE III. Chemical Surface Analysis by EDS for Permendur Samples (Bulk Refers to the Surface Without White Deposit)

\begin{tabular}{lcccccc}
\hline & \multicolumn{5}{c}{ Element (atomic \%) } \\
\cline { 2 - 7 } Area of analysis & $\mathrm{Fe}$ & $\mathrm{Co}$ & $\mathrm{V}$ & $\mathrm{O}$ & $\mathrm{Na}$ & $\mathrm{Cl}$ \\
\hline Bulk & 48.8 & 48.4 & 2.8 & 0 & 0 & 0 \\
White deposit & 33.5 & 28.1 & 2.3 & 5.8 & 22.8 & 7.5 \\
\hline
\end{tabular}




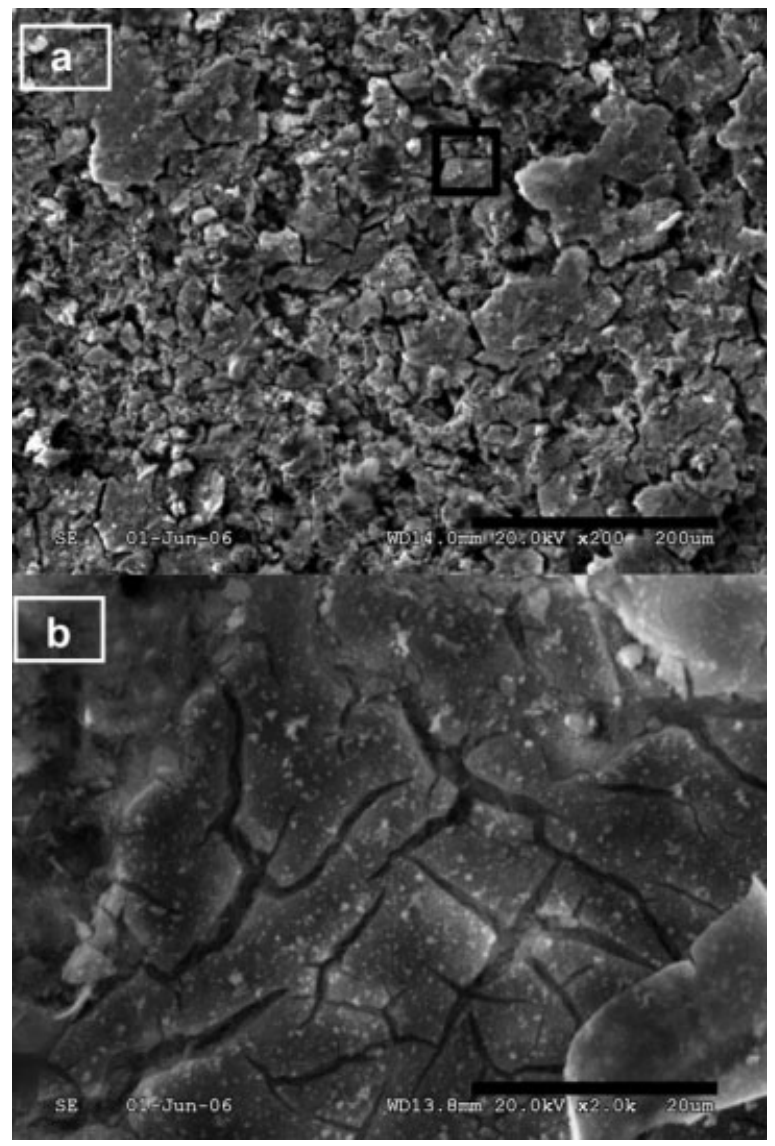

Figure 7. Vacoflux 17 SEM observations after the corrosion assay (a: X200, scale bar $=200 \mu \mathrm{m}$; b: X2000- Region of interest indicated on image (a), scale bar $=20 \mu \mathrm{m})$.

concentration in the supernatant of the Vacoflux 17 electrolyte was much higher than its concentration in the bulk alloy and in the precipitates.

\section{DISCUSSION}

The two Fe-Co alloys investigated presented neither the same corrosion parameters nor the same surface degradation. The main differences between the two alloys were the cobalt concentration and the presence of chromium in Vacoflux 17. For iron and cobalt based alloys for medical applications such as $316 \mathrm{~L}$ stainless steel $^{25}$ or Co-Cr-Mo alloy, ${ }^{26}$ chromium content must be near $10 \%$ to form a spontaneous passive film, increasing the corrosion resistance to values much higher than those obtained for Permendur and Vacoflux 17. ${ }^{27,28}$ However, Vacoflux 17 did not display a passivation interval (Fig. 3) because the chromium amount in the alloy (2\%) remained too low to form a stable protective layer. In Fe-Co alloys, the increase of chromium amount decreases the saturation magnetization. ${ }^{10}$ For example, $M \mathrm{~s}$ of a Fe-Co alloy with $10 \% \mathrm{Cr}$ decreased to $1.3 \mathrm{~T}$ which is $55 \%$ of Permendur $M \mathrm{~s}$. Because the highest magnetization is required for the propulsion in the
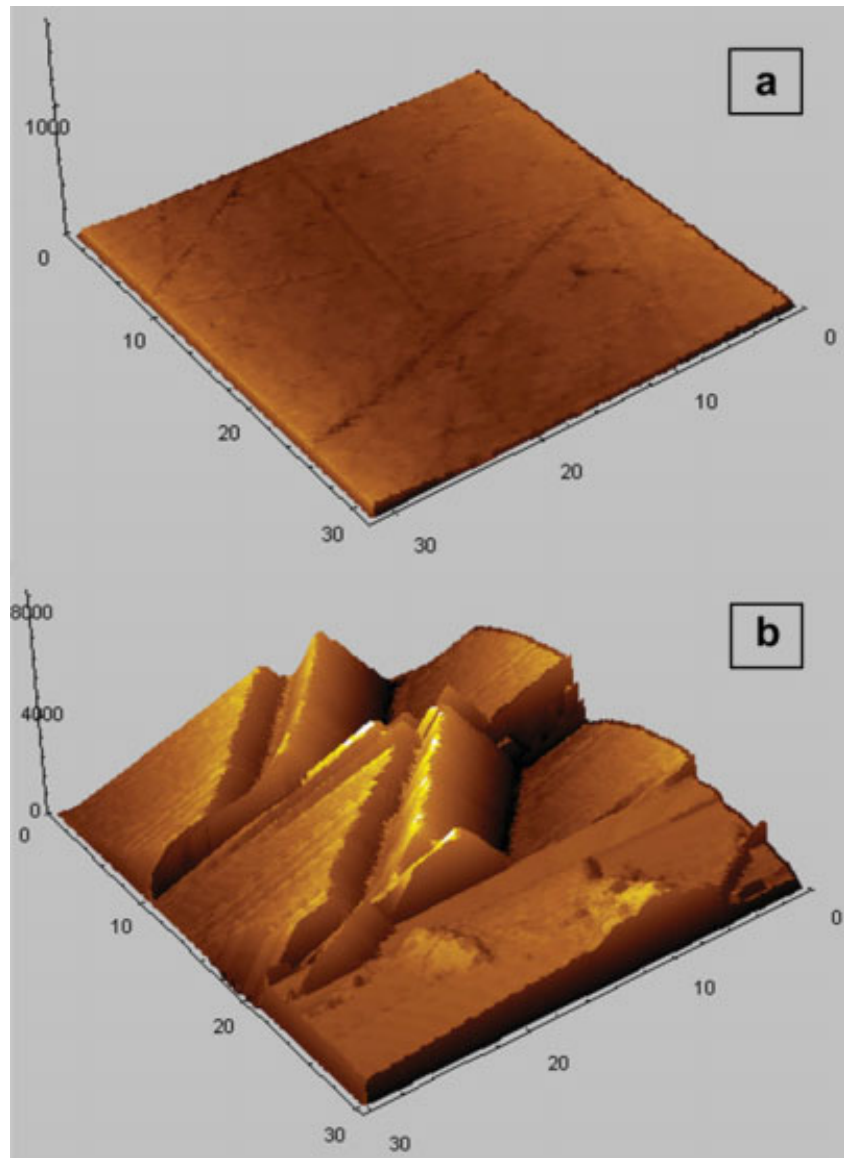

Figure 8. Vacoflux 17 sample surface morphology (a: polished surface, b: surface after the corrosion assay). The scale is in $\mathrm{nm}$. [Color figure can be viewed in the online issue, which is available at www.interscience.wiley.com.]

blood vessels, chromium proportion in Fe-Co alloys cannot be increased (Fig. 1).

The $E_{\text {ocp }}$ decrease observed for both Fe-Co alloys has confirmed that no stable protective layer was formed on the samples surface and/or the oxide layer was dissolved in the electrolyte, which is in agreement with results obtained previously on $\mathrm{SmCo}_{5}$ and $\mathrm{Nd}-\mathrm{Fe}-\mathrm{B}$ magnets used for dental implants. ${ }^{13,29}$ Metallic biomaterials $E_{\text {ocp }}$ increase $^{30}$ or stay stable. $^{25}$ The short stabilization of Vacoflux $17 E_{\text {ocp }}$ has confirmed that the chromium content was not high enough to form a stable protective layer.

For both alloys, the surface degradation was not promoted by defects on the surface before the corrosion assay because no polishing marks allowing local corrosion were detected by SEM and AFM analysis. The active-passive

TABLE IV. Surface Average Roughness of Permendur and Vacoflux 17 Samples Before and After Corrosion Assay

\begin{tabular}{lcc}
\hline & \multicolumn{2}{c}{ Surface average roughness $(\mathrm{nm})$} \\
\cline { 2 - 3 } Fe-Co alloys & Before corrosion & After corrosion \\
\hline Permendur & 261 & 1802 \\
Vacoflux 17 & 311 & 781 \\
\hline
\end{tabular}


TABLE V. Static Contact Angle Measurements Before the Corrosion Assay on Permendur and Vacoflux 17 Samples

\begin{tabular}{lc}
\hline Fe-Co alloys & Left angle $\left(^{\circ}\right)$ \\
\hline Permendur & $73.7 \pm 1.1$ \\
Vacoflux 17 & $84.9 \pm 1.4$ \\
\hline
\end{tabular}

transition (Fig. 2) can only partially protect the Permendur surface from degradation. ${ }^{24}$ The Permendur passivation can be attributed to the lower proportion of iron comparatively to Vacoflux 17 because iron is very susceptible to corrosion. ${ }^{15}$ However, this protective layer was not stable enough to prevent Permendur surface degradation during the corrosion assay. Moreover, the surface was not protected for a wide range of potentials during the reverse scan, and Permendur surface degradation occurred. The insoluble salts, deposited on the Permendur surface, came from interactions between the electrolyte and the sample surface. ${ }^{26}$ Chloride ions, known to be aggressive species, ${ }^{31}$ were involved in the Permendur surface degradation. The progressive change of morphology shown on AFM image (Fig. 6) resulted from the polycrystal structure degradation observed on SEM image [Fig. 5 (b)].

Because Permendur was more hydrophilic than Vacoflux 17 according to SCA measurements (Table V), the surface dissolution was higher for Permendur, as confirmed by the increase of the surface roughness. The stoichiometric dissolution of Permendur and Vacoflux 17 samples, determined by ICP-TOF-MS analysis, resulted from the constant degradation of the surface during the corrosion assay (Table VI). The high concentration of chromium ions found in the supernatant of Vacoflux 17 electrolyte confirmed the degradation of the unstable protective layer. The high concentration of cobalt ions compared with iron ion concentration in the Permendur supernatant resulted from the cobalt active dissolution. $^{27}$ Permendur has released a much higher amount of cobalt than Vacoflux 17 because the cobalt amount was higher in Permendur and the stoichiometric dissolution has occurred for both Fe-Co alloys.

The identification and the quantification of the ion release contribute to the determination of the biocompatibility of $\mathrm{Fe}-\mathrm{Co}$ alloys and their potential toxicity. In this context, a preliminary cytotoxicity assay has been previously done on these two Fe-Co alloys by our team. ${ }^{32}$ The cell viability, defined as the number of living cells in contact with Fe-Co alloys extracts divided by the number of living cells in their culture medium, was determined with (3-(4,5-dimethylthiazote-2yl)-2,5-diphenyl tetrazodium bromide) (MTT) assay done by indirect contact with mouse fibroblast cells L929. After immersion in cell culture medium Dulbecco's Modified Eagle's Medium during 5 days for the preparation of the extracts, Permendur and Vacoflux 17 samples were corroded, and the surfaces were characterized by a change of their morphology as observed after the corrosion assays. The cell viability for Permendur reached $53 \pm 1 \%$ after $24 \mathrm{~h}$ and decreased to $13 \pm 1 \%$ at
$48 \mathrm{~h}$ and to $8 \pm 1 \%$ at $72 \mathrm{~h}$. The cell viability obtained with Vacoflux 17 was higher, for example, $72 \pm 1 \%$ at $24 \mathrm{~h}, 27 \pm 2 \%$ at $48 \mathrm{~h}$, and $19 \pm 1 \%$ at $72 \mathrm{~h}$. As a reminder, cobalt, ${ }^{33-36}$ iron, ${ }^{37}$ vanadium, ${ }^{35,38}$ and chromium, ${ }^{39}$ present potential toxic effects such as carcinogenic and mutagenic action. ${ }^{35,40,41}$ According to ICP-TOF-MS analysis, all these elements were released during the corrosion assay. It can be concluded that Permendur cell viability remained lower than Vacoflux 17 cell viability because Permendur released a higher amount of cobalt ions. ${ }^{32}$ However, despite the fact that Vacoflux 17 released fewer cobalt ions, the cell viability obtained with this Fe-Co alloy at $72 \mathrm{~h}$ remained under the values obtained with biomedical materials. $^{42,43}$ From these results, both Fe-Co alloys cannot be considered as biocompatible materials.

This work has provided significant data for the design of medical magnetic microdevices with $\mathrm{Fe}-\mathrm{Co}$ alloys because a specific attention for its integration and the prevention of its degradation by corrosion is required. To avoid the surface degradation and the ion release, Fe-Co alloys surfaces have to be coated with a biocompatible material. ${ }^{44-49}$

\section{CONCLUSION}

Iron-cobalt alloys are the most suitable alloy for magnetic propulsion of a medical microdevice with an MRI system because of their high saturation magnetization. The corrosion of Permendur and Vacoflux 17 were different because of the presence of chromium in Vacoflux 17 and the high amount of cobalt in the Permendur. Permendur exhibited a low corrosion potential at $-0.57 \mathrm{~V} / \mathrm{SCE}$ and the corrosion rate was $13 \mu \mathrm{m} / \mathrm{yr}$. Despite a small passivation interval due to the amount of cobalt, the surface was uniformly degraded and no pit was formed. Vacoflux 17 possessed higher $E_{\text {corr }}$ of $-0.42 \mathrm{~V} / \mathrm{SCE}$, but the surface was damaged by cracks and pits. Vacoflux 17 did not possess enough chromium to form a stable protective layer. For both Fe-Co alloys, stochiometric dissolution in the electrolyte has occurred, and a high amount of ions was released. The amount of cobalt ions released from Permendur and Vacoflux 17 can induce cytotoxic effects. For these reasons, Fe-Co alloys should not be used for medical microdevices without a metallic or polymeric surface coating to prevent contact with physiological fluids.

TABLE VI. ICP-TOF-MS Analysis of Permendur and Vacoflux 17 Corrosion Precipitates and Supernatants

\begin{tabular}{lrrrr}
\hline & \multicolumn{4}{c}{ Concentration (ppb) } \\
\cline { 2 - 5 } Fe-Co alloys & \multicolumn{1}{c}{$F e$} & \multicolumn{1}{c}{ Co } & \multicolumn{1}{c}{$V$} & $C r$ \\
\hline Permendur precipitates & 8827 & 8880 & 473 & 0 \\
Permendur supernatant & 18 & 91 & 2 & 0 \\
Vacoflux 17 precipitates & 13643 & 2764 & 0 & 474 \\
Vacoflux 17 supernatant & 19 & 7 & 0 & 10 \\
\hline
\end{tabular}


This work was supported in part by a Canada Research Chair (CRC) in Micro/Nanosystem Development, Fabrication and Validation, the Canada Foundation for Innovation (CFI), the National Sciences and Engineering Research Council of Canada (NSERC), Fonds Québécois de la Recherche sur la Nature et les Technologies (FQRNT), Fonds de la Recherche en Santé du Québec (FRSQ) and the Government of Québec. The author acknowledges Stefania Polizu (LIAB) for the SEM images, Carole Massicotte and Josée Laviolette (École Polytechnique de Montréal) for their help with the samples preparation, Edith Martin (LECMEN) for the training to the corrosion tests, Huimin Tian (LECMEN) for the AFM analysis, and the companies Carpenter and Vacuumschmelze for Fe-Co samples.

\section{REFERENCES}

1. Schurr MO. Robotics and telemanipulation technologies for endoscopic surgery. A review of the ARTEMIS project. Surg Endosc 2000;14:375-381.

2. Guo S, Fukuda T, Asaka K. A new type of fish-like underwater microrobot. IEEE/ASME Transactis Mechatrics 2003;8: 136-141.

3. Edd J, Payen S, Rubinsky B, Stoller ML, Sitti M. Biomimetic Propulsion for a Swimming Surgical Micro-Robot. In IEEE International Conference on Intelligent Robots and Systems, Las Vegas, NV, 2003,2583-2588.

4. Behkam B, Sitti M. Design methodology for biomimetic propulsion of miniature swimming robots. J Dynamic Systems Meas Control Trans ASME 2006;128:36-43.

5. Martel S, Mathieu J-B, Felfoul O, Chanu A, Aboussouan E, Tamaz S, Pouponneau P, Yahia LH, Beaudoin G, Soulez G, Mankiewicz M. Automatic navigation of an untethered device in the artery of a living animal using a conventional clinical magnetic resonance imaging system. App Phys Lett 2007;90: 114105.

6. Mathieu J-B, Martel S, Yahia LH, Soulez G, Beaudoin G. Preliminary investigation of the feasibility of magnetic propulsion for future microdevices in blood vessels. Bio-Medical Mater Eng 2005;15:367-374.

7. Tamaz S, Gourdeau R, Chanu A, Mathieu J-B, Martel S. Real-time MRI-based control of a ferromagnetic core for endovascular navigation. IEEE Transactis Biomed Eng 2008; 55:1854-1863.

8. Felfoul O, Mathieu J-B, Beaudoin G, Martel S. In vivo MRtracking based on magnetic signature selective excitation. IEEE Transactis Med Imaging 2008;27:28-35.

9. Grief AD, Richardson G. Mathematical modelling of magnetically targeted drug delivery. J Magn Magn Mater 2005;293: 455-463.

10. Sourmail T. Near equiatomic FeCo alloys: Constitution, mechanical and magnetic properties. Prog Mater Sci 2005;50: 816-880.

11. Du Trémolet De Lacheisserie É. Magnétisme, I - Fondements, Les Ulis (France): EDP Sciences; 2000.

12. Noar JH, Evans RD, Wilson D, Costello J, Ioannou E, Ayeni A, Mordan NJ, Wilson M, Pratten J. An in vitro study into the corrosion of intra-oral magnets in the presence of dental amalgam. Eur J Orthod 2003;25:615-619.

13. Noar JH, Evans RD. Rare earth magnets in orthodontics: An overview. Br J Orthod 1999;26:29-37.

14. Preotu M, Filip D, Predeanu S, Tomorug A, Carciuleanu E, Ghitescu S. Thermical hysteresis loop of the alloys having Fe, Ni content used for magnetic sensors. Sens Actuators A Phys 2000;81:232-235.

15. Myung NV, Sumodjo PTA, Park D-Y, Yoo B-Y. Development of electroplated magnetic materials for MEMS. J Magn Magn Mater 2003;265:189-198.
16. Coutu L, Chaput L, Waeckerle T. 50.50 FeNi permalloy with $\mathrm{Ti}$ and $\mathrm{Cr}$ additions for improved hardness and corrosion resistance. J Magn Magn Mater 2000;215:237-239.

17. Eriksson H, Salwen A. 50 Permalloy alloyed with $\mathrm{Cr}$ for increased corrosion resistance. IEEE Transactis Magn 1977; 13:1451-1453.

18. Tavares SSM, Da Silva MR, Neto JM, Miraglia S, Fruchart D. Ferromagnetic properties of cold rolled AISI 304L steel. J Magn Magn Mater 2002;242:1391-1394.

19. Abreu CM, Cristobal MJ, Losada R, Novoa XR, Pena G, Perez MC. Effect of surface preparation on the evolution of the passive films formed on AISI 304L. Surf Interface Anal 2006;38:259-262.

20. Kumar BR, Singh R, Mahato B, De PK, Bandyopadhyay NR, Bhattacharya DK. Effect of texture on corrosion behavior of AISI 304L stainless steel. Mater Charact 2005;54:141-147.

21. Vacuumschmelze. Soft Magnetic Cobalt-Iron alloys, Available at: http://www.vacuumschmelze.de/dynamic/docroot/medialib/ documents/broschueren/htbrosch/Pht-004_e.pdf. Last assessed: 16 April 2009.

22. American Society for Testing and Materials. Annual Book of ASTM standard. Philadelphia: American Society for Testing and Materials; 2000.

23. Tian X, Emteborg H, Adams FC. Analytical performance of axial inductively coupled plasma time of flight mass spectrometry (ICP-TOFMS). J Anal At Spectrom 1999;14:1807-1814.

24. Assis SL, Rogero SO, Antunes RA, Padilha AF, Costa I. A comparative study of the in vitro corrosion behavior and cytotoxicity of a superferritic stainless steel, a Ti-13Nb-13Zr alloy, and an austenitic stainless steel in Hank's solution. J Biomed Mater Res B App Biomater 2005;73:109-116.

25. Leitao E, Silva RA, Barbosa MA. Electrochemical and surface modifications of $\mathrm{N}+$-ion-implanted 316L stainless steel. J Mater Sci Mater Med 1997;8:365-368.

26. Reclaru L, Luthy H, Eschler P-Y, Blatter A, Susz C. Corrosion behaviour of cobalt-chromium dental alloys doped with precious metals. Biomaterials 2005;26:4358-4365.

27. Hodgson AWE, Kurz S, Virtanen S, Fervel V, Olsson C-OA, Mischler S. Passive and transpassive behaviour of CoCrMo in simulated biological solutions. Electrochim Acta 2004;49: 2167-2178.

28. Hill D. Design engineering of biomaterials for medical devices, England: John Wiley \& Sons Ltd; 1998.

29. Gurrappa I. Corrosion studies related to suitability of permanent magnets for biomedical applications. Mater Charact 2002;48:63-70.

30. De Assis SL, Wolynec S, Costa I. Corrosion characterization of titanium alloys by electrochemical techniques. Electrochim Acta 2006;51:1815-1819.

31. Gallant D, Simard S. A study on the localized corrosion of cobalt in bicarbonate solutions containing halide ions. Corros Sci 2005;47:1810-1838.

32. Pouponneau P, Yahia LH, Merhi Y, Epure LM, Martel S. Biocompatibility of candidate materials for the realization of medical microdevices. Annual International Conference of the IEEE Engineering in Medicine and Biology, New York, NY, 2006,2362-2365.

33. De Boeck M, Kirsch-Volders M, Lison D. Cobalt and antimony: Genotoxicity and carcinogenicity. Mutat Res 2003;533: 135-152.

34. Barceloux DG. Cobalt. J Toxicol Clin Toxicol 1999;37:201206.

35. Cl W, Magos aeL, Suzuki T. Toxicology of metals, United States of America: CRC Press, Inc.; 1996.

36. Doran A, Law FC, Allen MJ, Rushton N. Neoplastic transformation of cells by soluble but not particulate forms of metals used in orthopaedic implants. Biomaterials 1998;19:751-759. 
37. Lehnen-Beyel I, Groot HD, Rauen U. Enhancement of iron toxicity in L929 cells by D-glucose: Accelerated (re-)reduction. Biochem J 2002;368:517-526.

38. Barceloux DG. Vanadium. J Toxicol Clin Toxicol 1999;37: 265-278.

39. Barceloux DG. Chromium. J Toxicol Clin Toxicol 1999;37: 173-194.

40. Seiler HG, Sigel H, Sigel A. Handbook on Toxicity of Inorganic compounds, United States of America: Marcel Dekker, Inc.; 1988.

41. Pereira ML, Abreu AM, Sousa JP, Carvalho GS. Chromium accumulation and ultrastructural changes in the mouse liver caused by stainless steel corrosion products. J Mater Sci Mater Med 1995;6:523-527.

42. Okazaki Y, Ito Y, Kyo K, Tateishi T. Corrosion resistance and corrosion fatigue strength of new titanium alloys for medical implants without V and Al. Mater Sci Eng A 1996;213:138-147.

43. Ahn H, Lee D, Moon C-W, Lee K-M, Lee K. A study about the bio-compatibility of Ti-8Ta-3Nb alloys with surface modification. Surf Coat Technol 2008;202:5779-5783.

44. Nygren H, Tengvall P, Lundstrom I. The initial reactions of $\mathrm{TiO}_{2}$ with blood. J Biomed Mater Res 1997;34:487-492.
45. Tsyganov I, Maitz MF, Wieser E. Blood compatibility of titanium-based coatings prepared by metal plasma immersion ion implantation and deposition. Appl Surf Sci 2004;235:156163.

46. Noar JH, Wahab A, Evans RD, Wojcik AG. The durability of parylene coatings on neodymium-iron-boron magnets. Eur $\mathrm{J}$ Orthod 1999;21:685-693.

47. Haidopoulos M, Turgeon S, Laroche G, Mantovani D. Chemical and morphological characterization of ultra-thin fluorocarbon plasma-polymer deposition on 316 stainless steel substrates: A first step toward the improvement of the longterm safety of coated-stents. Plasma Processes Polym 2005;2: 424-440.

48. Huang N, Leng YX, Yang P, Chen JY, Sun H, Wang J, Wan GJ, Zhao AS, Ding PD. Surface modification of coronary artery stent by $\mathrm{Ti}-\mathrm{O} / \mathrm{Ti}-\mathrm{N}$ complex film coating prepared with plasma immersion ion implantation and deposition. Nucl Instrum Methods Phys Res Sect B 2006; 242:18-21.

49. Spriano S, Verne E, Faga MG, Bugliosi S, Maina G. Surface treatment on an implant cobalt alloy for high biocompatibility and wear resistance. Wear 2005;259:919-925. 